ISSN 1392-3196 / e-ISSN 2335-8947

Zemdirbyste-Agriculture, vol. 103, No. 2 (2016), p. 135-142

DOI 10.13080/z-a.2016.103.018

\title{
The influence of primary soil tillage, deep loosening and organic fertilizers on weed incidence in crops
}

\author{
Regina SKUODIENĖ, Danutė KARČAUSKIENĖ, Regina REPŠIENĖ \\ Vėžaičiai Branch, Lithuanian Research Centre for Agriculture and Forestry \\ Gargždų 29, Véžaičiai, Klaipèda distr., Lithuania \\ E-mail: rskuod@vezaiciai.lzi.lt
}

\begin{abstract}
Little is known about the influence of deep loosening and its combination with primary soil tillage and organic fertilizers on weed incidence in crops. The aim of the study was to determine the influence of different soil tillage methods and their combinations with deep loosening and organic fertilizers on the weed incidence in a crop rotation. An experiment was carried out at Véžaičiai Branch of Lithuanian Research Centre for Agriculture and Forestry during the period 2012-2015 in a four-course crop rotation: winter wheat $\rightarrow$ spring rape $\rightarrow$ spring barley with undersown red clover $\rightarrow$ red clover. The soil of the experimental site is Dystri-Epihypogleyic Albeluvisol $(A B g-p-w-d y)$ with a sandy loam texture.

Soil tillage methods (conventional ploughing, shallow ploughing, shallow ploughless tillage), organic fertilizers (without organic fertilizers, straw, green manure $1^{\text {st }}$ cut + straw, green manure $2^{\text {nd }}$ cut + straw, farmyard manure 40 $\mathrm{t} \mathrm{ha}^{-1}+$ straw) and deep loosening impact on weed incidence was very unequal during the experimental years and depended on plant growth and development conditions.

In all experimental years, primary tillage had the main influence on the examined indicators of weed incidence (weed number and dry mass). Significantly greater number and mass of weeds were established in shallow ploughed soil. Organic fertilizers did not have any significant influence on the indicators of weed incidence; however, the use of red clover of the first cut for green manure tended to reduce weed number in the crops of the rotation during the first half of the plant growing season. A significant influence of a onetime deep loosening was observed in the first year. After improving soil aeration and humidity conditions, weed number and dry mass were significantly greater, compared to unloosened plots. The interaction between deep loosening and soil tillage methods had a great effect as well. Having used deep loosening in shallow ploughless tillage treatments, the weed number was greater compared to deeply ploughed soil.
\end{abstract}

Key words: primary soil tillage, soil fertility maintenance measures, weed number and mass.

\section{Introduction}

One of the main goals of modern agriculture is to produce economically beneficial crop yield, warranting soil ecological stability and steady renewal of its productivity.

The choice of tillage system changes the soil physical condition and soil organic matter content, which is an essential factor in building soil aggregates and creating favourable humidity and air conditions in the rhizosphere (Al-Kaisi et al., 2014). Appropriate soil tillage makes optimal conditions for crop growth by soil fertility maintenance and eradication of most weeds. According to the influence on the main soil qualitative indicators, there are two major soil tillage systems: conventional (deep ploughing) and reduced conservation soil tillage (direct sowing into stubble without soil disturbance, different intensity loosening without sward reversing and shallow ploughing) (Jodaugienè, 2002; Čiuberkis et al., 2008, De Sanctis et al., 2012).

Recently in Lithuania, various forms of reduced soil tillage have been increasingly used instead of annual conventional ploughing. Advantages of reduced tillage show up after 5-8 years in $0-10 \mathrm{~cm}$ soil layer. Due to the accumulation of nutrients and microorganism activity increase, most of the plant roots are spread in such depth (Jodaugiene, 2002). In such soils plant roots have limited depth of penetration and cope with water and nutritional stress during the dry period of the year (Novara et al., 2012). Compacted subsoil may reduce plant root growth with resulting effects on plant uptake of water and nutrients. Subsoil loosening may therefore be considered an option to increase nutrient use (Olesen, Munkholm, 2007).

Many authors (Stancevičius et al., 2002; Dorado, Lopez-Fando, 2006; Sans et al., 2011; Woźniak, Soroka, 2015) indicate that reduced soil tillage increases crop weediness. In slightly acidic West Lithuania's Dystric Albeluvisol with low content of organic matter, primary soil tillage had a significant impact on the weed incidence in the crops of the rotation. The highest number of weeds and their dry mass in winter wheat and spring rape stands was determined by applying shallow ploughless tillage, in spring barley - shallow ploughing and in the sward of red clover - deep and shallow ploughing (Skuodienè 
et al., 2013). Assessing the primary ploughless soil tillage influence on the weed incidence in crops in West Lithuania's weatherbeaten soils it was determined that it had the greatest impact on perennial weeds whose population changes were more consistent than those of the annual weeds because of reduced soil tillage. After deep soil cultivating with a universal cultivator in the second year and after conventional ploughing, deep loosening or direct sowing in the third year, Sonchus arvense L., Cirsium arvense L., Taraxum officinale F.H. Wigg. disappeared from the crop of spring barley and winter wheat. Direct seeding increased the number of Elytrigia repens (L.) Nevski by $67.5 \%$ in the first and subsequent years (Kinderiené, 2014). Increased abundance of perennial weeds is a response to reduced tillage, among other factors (Torresen et al., 2003). Ploughless soil tillage combination with lime sludge incorporation in favourable conditions of barley germination and growth warranted the thickest crops, good barley development and weed competitive ability as well as a significant barley yield increase compared to conventional ploughing (Velykis, Satkus, 2012). According to the data of some researchers (Murphy et al., 2006), appropriate reduced soil tillage can reduce crop weediness. Proper agricultural systems can influence the quality of the environment. Consequently, it is worth searching for soil tillage and its combinations with other crop and soil management practices (deep loosening, organic fertilization) which would have the least negative effect on the stability of the agroecosystem.

Hypothesis. We hypothesize that under the effect of long-term different intensity soil tillage and its combinations with deep loosening and organic fertilizers there will develop the soil environment different in humidity, air and nutrition conditions. This could influence not only the abundance of agricultural plants but also the crop rotation weediness. Deep loosening will be significant for the changes in weed incidence as it creates favourable humidity and aeration conditions at 35-40 cm depth of the soil profile especially in the first year. The aim of the study was to determine the influence of different soil tillage methods and their combinations with deep loosening and organic fertilizers on the weed incidence in a crop rotation.

\section{Materials and methods}

Site and soil description. The soil of the experimental site is Dystri-Epihypogleyic Albeluvisol $(A B g-p-w-d y)$ with a texture of sandy loam (clay particles $<0.002 \mathrm{~mm}-13-15 \%)$, whose $\mathrm{pH}$ at the beginning of the trial was 5.1-5.3. The soil is moderate in humus status (humus $-2.43 \%$, organic carbon $-1.41 \%$ ), moderate in mobile phosphorus content and high in mobile potassium (106 and $270 \mathrm{mg} \mathrm{kg}^{-1}$ soil, respectively).

The trial was carried out in 2003 in the experimental crop rotation field of Vèžaičiai Branch of Lithuanian Research Centre for Agriculture and Forestry. In 2012, the trial was continued for the third crop rotation by sowing winter wheat in the autumn. The four-course crop rotation consisted of winter wheat (Triticum aestivum L.) var. 'Ada' (2012), spring rape (Brassica napus L. ssp. oleifera annua Metzg) var. 'Acheras' (2013), spring barley (Hordeum vulgare L.) var. 'Luokè' with undersown red clover (2014), red clover (Trifolium pratense L.) var. 'Sadūnai' of the first year of use (2015).
Trial plot sizes. The net plot size was $10 \times 5=$ $50 \mathrm{~m}^{2}$. The harvested area for cereals and rape amounted to $4 \times 6.6=26.4 \mathrm{~m}^{2}$ and for clover $4 \times 4.2=16.8 \mathrm{~m}^{2}$. The trial was replicated four times. Blocks of factor A and treatments in the replications were randomised.

Trial factors and treatments. Factor A. Primary soil tillage: 1) conventional ploughing (20-25 cm), 2) shallow ploughing $(10-12 \mathrm{~cm}), 3)$ shallow ploughless tillage $(8-10 \mathrm{~cm})$. Factor B. Organic fertilizers: 1) without organic fertilizers, 2) straw, 3) green manure $1^{\text {st }}$ cut + straw, 4) green manure $2^{\text {nd }}$ cut + straw, 5) farmyard manure $40 \mathrm{t} \mathrm{ha}^{-1}+$ straw. Factor C. Deep loosening: 1) unloosened, 2) loosening at $35-40 \mathrm{~cm}$ every four years.

In 2011, the phytomass of red clover was incorporated into the soil according to the design of factor B. The phytomass of clover was removed from the plots of the first, the second and the fifth treatments. The phytomass of clover from the plots of the third and the fourth treatments was spread: 1.37, 0.94 and $0.49 \mathrm{t} \mathrm{ha}^{-1}$ dry matter (DM) yield of the $1^{\text {st }}$ cut in A1, A2, A3 bars and $2.45,2.32,1.43 \mathrm{tha}^{-1} \mathrm{DM}$ yield of the $2^{\text {nd }}$ cut in $\mathrm{A} 1, \mathrm{~A} 2$, A3 bars, respectively. In the plots of the fifth treatment $40 \mathrm{t} \mathrm{ha}^{-1}$ farmyard manure was spread. Organic fertilizers were incorporated with a disc stubble cultivator. Before the primary soil tillage, trial plots were divided in two sections (10 m bars); deep loosening $(35-40 \mathrm{~cm})$ was accomplished in one of them in order to modify compacted subsoil which had formed after the steady cultivation in one depth during two crop rotations ( 8 years). After three weeks, the plots of the first treatment of factor A were deeply ploughed with a plough fitted with semi screw moalboard, those of the second treatment were shallow ploughed and the plots of the third treatment were cultivated with a spring-tine cultivator. Before sowing, the soil was cultivated with a pre-sowing soil tillage cultivator and on the $17^{\text {th }}$ of September the winter wheat was sown with a disc seed drill "Fiona SD-977" (Fiona Maskinfabrik A/S, Denmark).

In 2012, after winter wheat harvesting, the straw was removed from the first treatment of factor B; the straw $\left(4.0 \mathrm{t} \mathrm{ha}^{-1}\right)$ of the second-fifth treatments was chopped and spread at harvesting with a combine harvester "Sampo 500" (Sampo Rosenlew, Finland). After spreading the straw of winter wheat and rape, a rate of $10 \mathrm{~kg}$ nitrogen was distributed per each ton of straw. In 2014, after spring barley harvesting, the straw was collected and removed.

Crops were fertilized with mineral fertilizers. The rate for the stand of winter wheat was $\mathrm{N}_{90} \mathrm{P}_{60} \mathrm{~K}_{90}$, for the spring rape $-\mathrm{N}_{150} \mathrm{P}_{90} \mathrm{~K}_{150}$, for the spring barley $-\mathrm{N}_{60} \mathrm{P}_{60} \mathrm{~K}_{90}$ and for the red clover $-\mathrm{P}_{90} \mathrm{~K}_{90}$. Before sowing, the grains of winter wheat and spring barley were treated with Kinto (triticonazole + prochloraze) at a rate of 21 per ton.

Plant protection products (pesticides) were used. In 2012, at BBCH 23 MCPA Super (MCPA) $1.01 \mathrm{ha}^{-1}$ + Banvel 4S (Dikamba) $0.31 \mathrm{ha}^{-1}$, at $\mathrm{BBCH} 47$ Opera $\mathrm{N}$ (pyraclostrobin + epoxiconazole) $2.01 \mathrm{ha}^{-1}$, at $\mathrm{BBCH}$ 71 Akanto prima (picoxistrobin + cyprodinil) $1.5 \mathrm{~kg} \mathrm{ha}^{-1}$ were used. In 2013, at BBCH 13-14 Galera (clopyralid + picloram) $0.351 \mathrm{ha}^{-1}$, at BBCH 16 Fury (zeta cypermethrin) $0.1 \mathrm{l} \mathrm{ha}^{-1}$, at BBCH 32 Galera (clopyralid + picloram) $0.351 \mathrm{ha}^{-1}+$ Trend $0.021 \mathrm{ha}^{-1}$ were used. In 2014, at BBCH 49 Alegro super (krezoksim-metil + epoxiconazol + fenpropimorph) $1.51 \mathrm{ha}^{-1}+$ Fury (zeta cypermethrin) $0.1 \mathrm{haa}^{-1}$, at BBCH 49-55 (57) Juventus 90 (metconazole) $1.01 \mathrm{ha}^{-1}$ were used. 
Methods of analysis. Weed record was performed in stationary areas $0.25 \mathrm{~m}^{-2}$ in size in two positions of every plot during crop shooting and maturity phases. Weediness in the sward of red clover was estimated before the first cut. During the first record, weed species composition was determined, during the second record the weeds were eradicated and their specific composition and dry matter mass were determined. Weed number was recalculated to weeds per $\mathrm{m}^{2}$ and mass $-\mathrm{g} \mathrm{m}^{-2}$. Soil $\mathrm{pH}_{\mathrm{KCl}}$ was determined using potentiometric method, $\mathrm{N}_{\text {tot }}$ - using Kjeldahl method, available $\mathrm{P}_{2} \mathrm{O}_{5}$ and $\mathrm{K}_{2} \mathrm{O}$ - using Egner-Riehm-Domingo (A-L) method. Soil texture was determined according to the composition of three fractions: sand, silt and clay. Analysis was accomplished using Kaczynski method and modified according to FAO.
Agrometeorological conditions. Meteorological conditions were different during the period 2012-2015 (Table 1). The temperature in 2012 was close to the long-term mean. The amount of precipitation was 1.2 times greater and during the growing season it was 1.4 times greater than the long-term mean. Humid and warm weather conditions during the growing season in 2013 were favourable for the growth of spring rape. The growing season in 2014 was warm and dry; therefore the conditions for the growth of spring barley and red clover were unfavourable. The spring in 2015 was warm and wet. In spring time, the temperature and the amount of rainfall were close to the long-term mean; however, the rainfall distribution was very uneven.

Table 1. Weather conditions for 2012-2015 (the data from the Véžaičiai Meteorological Station)

\begin{tabular}{|c|c|c|c|c|}
\hline Year & 2012 & 2013 & 2014 & 2015 \\
\hline Annual mean air temperature, ${ }^{\circ} \mathrm{C}$ & 6.8 & 7.5 & 8.0 & 8.1 \\
\hline Difference from long-term mean, ${ }^{\circ} \mathrm{C}$ & 0 & +0.7 & +1.2 & +1.2 \\
\hline Growing season's mean air temperature, ${ }^{\circ} \mathrm{C}$ & 12.7 & 13.2 & 13.3 & 12.0 \\
\hline Difference from long-term mean, ${ }^{\circ} \mathrm{C}$ & +0.5 & +1.0 & +1.1 & -0.2 \\
\hline Total annual precipitation , $\mathrm{mm}$ & 1003.9 & 838.6 & 719.9 & 914.6 \\
\hline Total annual precipitation as percentage of the long-term mean, $\%$ & 116.5 & 97.4 & 79.2 & 106.4 \\
\hline Growing season's total precipitation, $\mathrm{mm}$ & 727.1 & 510.6 & 414.4 & 431.9 \\
\hline Difference from long-term mean, mm & +201.7 & -14.5 & -109.4 & -91.5 \\
\hline
\end{tabular}

The experimental data were analysed by a threefactor analysis of variance. Significance of the differences between the means was determined according to the Fisher's protected least significant difference (LSD) at 0.05 probability level. The data were processed using software ANOVA (spilt-plot-plot) (Clewer, Scarisbrick, 2001). Data of weed density and biomass were transformed, according to the recommended procedures, using equation $\mathrm{Y}=\operatorname{Sqr}(\mathrm{x}+1)$; however, means on the original scales are reported (Onofri et al., 2010). Correlation-regression analysis was also performed.

\section{Results and discussion}

The weed incidence in the crop rotation. Weed species populations are dynamic and change in time, spread and environment (Booth et al., 2003). Their seedling number is directly proportional to the temperature and soil humidity potential (Grundy, 1997) as well as the depth of the seed burial in the soil (Colbach et al., 2006). Analysis of variance of weed number and mass revealed the significant influence of primary soil tillage (factor $\mathrm{A}$ ) on the examined indicators of weediness (Table 2). During all the experimental years, in shallow tillage soil the number and mass of weeds were significantly greater compared to conventional ploughing. Soil fertility maintenance measures (organic fertilizers, factor B) did not have significant influence on the indicators of weed incidence. The significant impact of the onetime deep loosening (factor C) showed up during the first year (2012). After improving soil aeration

Table 2. Significance of the effect of primary soil tillage, organic fertilizers and deep loosening on weed incidence parameters according to $F$-test

\begin{tabular}{|c|c|c|c|c|c|c|c|c|c|}
\hline \multirow{2}{*}{$\begin{array}{l}\text { Investigation } \\
\text { period }\end{array}$} & \multirow{2}{*}{$\begin{array}{l}\text { Indicators } \\
\text { of weed } \\
\text { incidence }\end{array}$} & \multirow{2}{*}{ Year } & \multicolumn{7}{|c|}{ Actions and interactions } \\
\hline & & & A & $\mathrm{B}$ & $\mathrm{C}$ & $\mathrm{A} \times \mathrm{B}$ & $\mathrm{A} \times \mathrm{C}$ & $\mathrm{B} \times \mathrm{C}$ & $\mathrm{A} \times \mathrm{B} \times \mathrm{C}$ \\
\hline \multirow[t]{3}{*}{ Shooting } & \multirow{4}{*}{$\begin{array}{c}\text { weed } \\
\text { number }\end{array}$} & 2012 & $15.60 * *$ & ns & $25.62 * *$ & ns & $3.93^{*}$ & ns & ns \\
\hline & & 2013 & $153.07 *$ & ns & ns & ns & ns & ns & ns \\
\hline & & 2014 & $7.44 * *$ & ns & ns & ns & $5.59 * *$ & ns & ns \\
\hline Flowering & & 2015 & $27.94 * *$ & ns & ns & ns & $6.20 * *$ & ns & ns \\
\hline \multirow{3}{*}{ Maturity } & \multirow{3}{*}{$\begin{array}{c}\text { weed } \\
\text { number }\end{array}$} & 2012 & $10.32 * *$ & ns & $9.78 * *$ & ns & ns & ns & ns \\
\hline & & 2013 & $63.21 * *$ & ns & ns & ns & $5.37 * *$ & ns & ns \\
\hline & & 2014 & ns & ns & ns & ns & ns & ns & ns \\
\hline \multirow{3}{*}{ Maturity } & \multirow{3}{*}{ DM mass } & 2012 & ns & ns & $12.91 * *$ & ns & ns & ns & ns \\
\hline & & 2013 & $52.29 * *$ & ns & ns & ns & ns & ns & ns \\
\hline & & 2014 & $15.16 * *$ & ns & $4.48 *$ & ns & ns & ns & ns \\
\hline \multirow[t]{3}{*}{ Shooting } & \multirow{4}{*}{$\begin{array}{c}\text { number of } \\
\text { species }\end{array}$} & 2012 & $9.07 * *$ & ns & $5.02 * *$ & ns & ns & ns & ns \\
\hline & & 2013 & $55.56 * *$ & $\mathrm{~ns}$ & ns & ns & ns & $\mathrm{ns}$ & ns \\
\hline & & 2014 & ns & ns & ns & ns & ns & ns & ns \\
\hline Flowering & & 2015 & $11.21 * *$ & ns & ns & ns & ns & ns & ns \\
\hline \multirow{3}{*}{ Maturity } & \multirow{3}{*}{$\begin{array}{c}\text { number of } \\
\text { species }\end{array}$} & 2012 & ns & ns & ns & ns & ns & ns & ns \\
\hline & & 2013 & $21.34 * *$ & ns & ns & ns & ns & ns & ns \\
\hline & & 2014 & $24.41 * *$ & ns & ns & ns & $3.6^{*}$ & ns & ns \\
\hline
\end{tabular}

A - factor A: primary soil tillage, B - factor B: organic fertilizers, C - factor C: deep loosening; * and ** - the least significant at $P<0.05$ and $P<0.01$, respectively; ns - not significant 
and humidity conditions, the weed number and dry matter mass in the first half of the growing season and before harvesting were significantly greater compared to unloosened plots. Deep loosening interaction with soil tillage methods had the significant impact as well. Using deep loosening in shallow ploughless tillage soil the weed number was greater in many ways compared to conventional ploughing and unloosened soil.

The effect of diverse soil and crop management practices on weed germination. Under shallow ploughing, in winter wheat stand in autumn (2012) and during the shooting stage in spring, the weed number was $14.2 \%$ greater, and in spring rape stand (2013) by $114.3 \%$ greater compared to weed number under conventional ploughing (Table 3). Under shallow ploughing and shallow ploughless tillage, the weed incidence in spring barley with undersown clover (2014) and red clover (2015) was by $46.6 \%$ and $25.4 \%, 41.8 \%$ and $118.5 \%$ higher, respectively, compared to that under conventional ploughing. Significant differences were obtained every year.

While attempting to reduce the environmental pollution it is very important to apply soil fertility improvement measures. Different plant species ploughed in as green manure and unequal amounts of nutrients in the soil have a significant impact on the indicators of cereal productivity (Skuodiene, Nekrosiene, 2012), red clover biomass ploughed in as green manure reduces crop weediness (Maikštėnienè et al., 2009). According to our data, the use of red clover of the first cut as green manure, had tended to reduce weed number in the crop rotation for two years out of four examined. A significant impact was determined in the next year after the red clover biomass insertion in 2012, when the weed number in winter wheat was $21.4 \%$ less than after ploughing only stubble (Table 3). Spring barley with undersown clover (2014) formed better competitive ability and this had a positive tendency to reduce weediness, therefore the weed number decreased by 10.1\%. In 2013 and 2015, in the crops of the rotation the weed number was estimated similar to that after stubble ploughing. The weed number in stands with other soil fertility improvement measures (organic fertilizers) varied insignificantly.

Table 3. The effect of primary soil tillage, organic fertilizers and deep loosening on the weed emergence (weed number per $\mathrm{m}^{2}$ )

\begin{tabular}{|c|c|c|c|c|}
\hline Treatment & $\begin{array}{c}\text { Winter wheat } \\
2012 \\
\end{array}$ & $\begin{array}{c}\text { Spring rape } \\
2013 \\
\end{array}$ & $\begin{array}{c}\text { Spring barley } \\
2014 \\
\end{array}$ & $\begin{array}{c}\text { Red clover } \\
2015 \\
\end{array}$ \\
\hline \multicolumn{5}{|c|}{ Primary soil tillage (factor A) } \\
\hline Conventional ploughing & 93.9 & 163.0 & 196.5 & 18.9 \\
\hline Shallow ploughing & 79.1 & 164.0 & $248.5 * *$ & $26.8 *$ \\
\hline Shallow ploughless tillage & $121.7 * *$ & $349.3 * *$ & 212.6 & $41.3 * *$ \\
\hline \multicolumn{5}{|c|}{ Organic fertilizers (factor B) } \\
\hline Without organic fertilizers & 106.8 & 213.9 & 231.2 & 26.2 \\
\hline Straw & 98.3 & 236.7 & 222.3 & 30.3 \\
\hline Green manure $1^{\text {st }}$ cut + straw & $83.9 *$ & 214.2 & 207.9 & 26.8 \\
\hline Green manure $2^{\text {nd }}$ cut + straw & 101.8 & 229.3 & 221.2 & 30.7 \\
\hline Farmyard manure $40 \mathrm{t} \mathrm{ha}^{-1}+$ straw & 100.4 & 233.0 & 213.4 & 30.9 \\
\hline \multicolumn{5}{|c|}{ Deep loosening (factor C) } \\
\hline Unloosened & 82.2 & 230.5 & 214.5 & 28.3 \\
\hline Loosened & $114.3 * *$ & 220.3 & 223.9 & 29.7 \\
\hline \multicolumn{5}{|c|}{ Interaction of factors $\mathrm{A} \times \mathrm{C}$} \\
\hline $\mathrm{A} 1 \times \mathrm{C} 1$ & 68.4 & 167.2 & 176.5 & 18.5 \\
\hline $\mathrm{A} 1 \times \mathrm{C} 2$ & $119.5^{* *}$ & 158.8 & $216.5^{*}$ & 19.2 \\
\hline $\mathrm{A} 2 \times \mathrm{C} 1$ & 75.1 & 169.3 & $269.6^{* *}$ & $32.1 * *$ \\
\hline $\mathrm{A} 2 \times \mathrm{C} 2$ & 83.2 & 158.6 & $227.4 * *$ & 21.5 \\
\hline $\mathrm{A} 3 \times \mathrm{C} 1$ & $103.1 * *$ & $355.1 * *$ & 197.5 & $34.1 * *$ \\
\hline $\mathrm{A} 3 \times \mathrm{C} 2$ & $140.3^{* *}$ & $343.6^{* *}$ & $227.7 * *$ & $48.4^{* *}$ \\
\hline
\end{tabular}

* - significant at $P \leq 0.05, * *$ - significant at $P \leq 0.01$

In the first year (2012), after deep loosening, the weed number was significantly greater (by 39.0\%) compared to the plots without deep loosening (Table 3). In the next year (2013, 2014 and 2015, respectively), the weed number data were inconsistent and the differences were insignificant.

Deep loosening interaction with soil tillage methods had a significant impact as well. In 2012 and 2014, after deep loosening and conventional ploughing the plots had by 1.7 and 1.2 times respectively higher weed incidence than without deep loosening plots. In 2012, 2013 and 2015, after deep loosening and shallow ploughless tillage the plots had the highest weed incidence compared to the other plots.

Weed number and dry mass at crop maturity stage. In the crop rotation agrocenosis, starting from crop shooting until maturity, a part of weeds disappeared. In 2012 and 2013, the weed number in winter wheat and spring rape decreased by 1.4-1.9 times. In spring barley with undersown red clover (2014), the weed number decreased more significantly by $1.9-2.8$ times. Spring barley with undersown clover had a greater competitive ability which resulted in reduced number of weeds (Table 4).

The impact of soil tillage methods on the crop weed incidence persisted at the stage of crop maturity. Before harvesting, in shallow ploughless tillage, in winter wheat stand (2012), the weed number was $63.3 \%$ greater and in spring rape stand (2013), in shallow ploughing and shallow ploughless tillage plots, it was $35.9 \%$ and $86.9 \%$ greater, compared to that in the conventionally ploughed soil (Table 4). In spring barley stand (2014), there were 
Table 4. The effect of primary soil tillage, organic fertilizers and deep loosening on the weed incidence in the crop stands of the rotation during the maturity stage

\begin{tabular}{|c|c|c|c|c|c|c|}
\hline \multirow[b]{2}{*}{ Treatment } & \multicolumn{2}{|c|}{$\begin{array}{c}\text { Winter wheat } \\
2012\end{array}$} & \multicolumn{2}{|c|}{$\begin{array}{c}\text { Spring rape } \\
2013 \\
\end{array}$} & \multicolumn{2}{|c|}{$\begin{array}{c}\text { Spring barley } \\
2014\end{array}$} \\
\hline & $\begin{array}{c}\text { weed } \\
\text { number } \\
\mathrm{m}^{-2}\end{array}$ & $\begin{array}{l}\text { weed mass } \\
\text { DM } \mathrm{g} \mathrm{m}^{-2}\end{array}$ & $\begin{array}{c}\text { weed } \\
\text { number } \\
\mathrm{m}^{-2}\end{array}$ & $\begin{array}{l}\text { weed mass } \\
\text { DM } \mathrm{g} \mathrm{m}^{-2}\end{array}$ & $\begin{array}{c}\text { weed } \\
\text { number } \\
\mathrm{m}^{-2}\end{array}$ & $\begin{array}{c}\text { weed mass } \\
\text { DM } \mathrm{g} \mathrm{m}^{-2}\end{array}$ \\
\hline \multicolumn{7}{|c|}{ Primary soil tillage (factor A) } \\
\hline Conventional ploughing & 49.9 & 27.5 & 120.5 & 109.6 & 90.2 & 27.0 \\
\hline Shallow ploughing & 53.8 & 35.0 & $163.8 * *$ & 108.6 & 90.2 & 30.0 \\
\hline Shallow ploughless tillage & $81.5 * *$ & 34.0 & $225.2 * *$ & $204.3 * *$ & 88.2 & $50.0 * *$ \\
\hline \multicolumn{7}{|c|}{ Organic fertilizers (factor B) } \\
\hline Without organic fertilizers & 57.7 & 35.5 & 175.1 & 135.8 & 101.1 & 36.2 \\
\hline Straw & 60.8 & 27.0 & 174.6 & 143.9 & 87.6 & 28.1 \\
\hline Green manure $1^{\text {st }}$ cut + straw & 52.6 & 34.8 & 163.7 & 129.0 & 87.2 & 36.7 \\
\hline Green manure $2^{\text {nd }}$ cut + straw & 68.4 & 33.8 & 165.8 & 135.1 & 83.4 & 37.8 \\
\hline Farmyard manure $40 \mathrm{t} \mathrm{ha}^{-1}+$ straw & 69.2 & 29.7 & 170.1 & 160.3 & 88.3 & 39.6 \\
\hline \multicolumn{7}{|c|}{ Deep loosening (factor $\mathrm{C}$ ) } \\
\hline Unloosened & 51.2 & 20.5 & 173.9 & 148.7 & 91.1 & 32.4 \\
\hline Loosened & 72.2 & $43.8 * *$ & 165.8 & 133.0 & 88.0 & 39.0 \\
\hline \multicolumn{7}{|c|}{ Interaction of factors $\mathrm{A} \times \mathrm{C}$} \\
\hline $\mathrm{A} 1 \times \mathrm{C} 1$ & 36.9 & 11.8 & 111.3 & 212.1 & 93.2 & 21.3 \\
\hline $\mathrm{A} 1 \times \mathrm{C} 2$ & $62.9 *$ & $43.2 * *$ & 129.7 & 98.2 & 87.2 & $32.8 *$ \\
\hline $\mathrm{A} 2 \times \mathrm{C} 1$ & 47.7 & 18.6 & $163.2 * *$ & 105.6 & 88.7 & 26.9 \\
\hline $\mathrm{A} 2 \times \mathrm{C} 2$ & $59.9 *$ & $51.4 * *$ & $164.4 * *$ & 111.6 & 91.7 & $33.1 *$ \\
\hline $\mathrm{A} 3 \times \mathrm{C} 1$ & $69.1 * *$ & $31.2 *$ & $247.1 * *$ & $219.4 * *$ & 91.5 & $48.8 * *$ \\
\hline $\mathrm{A} 3 \times \mathrm{C} 2$ & $93.9 * *$ & $36.7 * *$ & $203.3 * *$ & $189.2 * *$ & 84.9 & $51.2 * *$ \\
\hline
\end{tabular}

* - significant at $P \leq 0.05, * *$ - significant at $P \leq 0.01$

no significant differences in weed incidence among different soil tillage methods. In autumn, different soil cultivation methods had an ambiguous influence on weed dry mass. The weed mass in shallow ploughed soil was significantly greater in spring rape and barley stands, by $86.4 \%$ and $85.2 \%$, respectively. Soil fertility maintenance measures did not have any significant impact on the weed incidence in crop stands (weed number and dry matter mass) (Table 4, factor B).

In the first year (2012), in the plots after the deep loosening, during the crop maturity stage, the weed number was greater $(41.0 \%)$ and weed mass was significantly greater $(113.6 \%)$, compared to the plots without deep loosening (Table 4, factor C). In the stands of spring rape (2013) and spring barley (2014), the weed number after deep loosening was $4.6 \%$ and $3.4 \%$ lower, but the differences were not significant. The data of the weed dry mass were inconsistent: in 2013 the mass was $10.6 \%$ lower, and in 2014 it was $20.4 \%$ greater.

Results of the interaction of factors $\mathrm{A} \times \mathrm{C}$ show that in 2012 after deep loosening in the plots of different soil tillage the weed number and weed mass were greater by $1.3-1.7$ and 1.2-3.7 times, respectively compared to the plots without deep loosening. In the other experimental years the data of weed number and mass were inconsistent.

Weed species variation in the crops of the rotation during the plant growing season. References indicate, that under traditional farming system the mean number of weed species is 4.9 (Edesi et al., 2012). Other researchers indicate that in the fields or crops of intensive agriculture there are found 9-13 weed species (Baležentienè, 2008; Kolárová et al., 2013) while in those of low intensity agriculture - about 20 (Hyvönen, Salonen, 2002). Eiswerth and Haney (2001) have noted the reciprocity between and dependence of farming types (different soil tillage, mineral fertilizers, pesticide) on the variety of plant species. The results of our study show that soil tillage methods and applied agrotechnical measures (onetime deep loosening) changed the diversity of weed species (Table 5). After the deep loosening, at the stage of plant shooting in winter wheat (2012) and at the stage of shooting and maturity in spring rape stands (2013) the species composition was determined significantly (respectively 15.2, 34.2 and $46 \%$ ) greater in shallow tillage soil plots compared to deep ploughing. The greatest (7-10 species) number of weed species was determined in 2013 when humid and warm weather during the growing season was favourable not only for spring rape but also for weed growth and development. A high number of weed species (8-9 species) was determined also in 2014 during the shooting stage of spring barley with undersown clover. However, in barley mixed with legume, until the crop maturity stage the weed species number decreased 1.9 times in shallow ploughless tillage plots, 2.6 times in conventional ploughing plots and 3.4 times in shallow ploughing plots. This shows a good competitive ability of the grass and legume mixture (Szumigalski, Van Acker, 2005).

After the warm winter, in the normal density sward of the red clover (2015) the weed number was low 18.9-41.3 weeds $\mathrm{m}^{-2}$ (Table 3), therefore the number of species was determined also minor, only 3-4 species (Table 5). Application of shallow ploughing and shallow ploughless tillage in the sward of the red clover, determined 1.2-1.4 times more weed species than conventional tillage method.

The results of the interaction of factors $\mathrm{A} \times \mathrm{C}$ show that in 2012 and 2014, at the stage of shooting after deep loosening and conventional ploughing the weed species diversity in the plots was greater compared to the plots without deep loosening. 
Table 5. Number of weed species, species per $\mathrm{m}^{2}$

\begin{tabular}{|c|c|c|c|c|c|c|c|}
\hline \multirow[t]{2}{*}{ Treatment } & \multicolumn{2}{|c|}{$\begin{array}{c}\text { Winter wheat } \\
2012 \\
\end{array}$} & \multicolumn{2}{|c|}{$\begin{array}{c}\text { Spring rape } \\
2013\end{array}$} & \multicolumn{2}{|c|}{$\begin{array}{c}\text { Spring barley } \\
2014 \\
\end{array}$} & \multirow{2}{*}{$\begin{array}{c}\text { Red clover } \\
2015 \\
\text { flowering }\end{array}$} \\
\hline & shooting & maturity & shooting & maturity & shooting & maturity & \\
\hline \multicolumn{8}{|c|}{ Primary soil tillage (factor A) } \\
\hline Conventional ploughing & 5.9 & 4.2 & 7.3 & 6.3 & 8.7 & 3.4 & 3.0 \\
\hline Shallow ploughing & 5.7 & 3.8 & 7.5 & $7.4^{*}$ & 9.5 & $2.8 * *$ & $3.6^{*}$ \\
\hline Shallow ploughless tillage & $6.8^{* *}$ & 4.0 & $9.8 * *$ & $9.2 * *$ & 8.8 & $4.6^{* *}$ & $4.3 * *$ \\
\hline \multicolumn{8}{|c|}{ Organic fertilizers (factor B) } \\
\hline Without organic fertilizers & 6.5 & 3.8 & 8.1 & 8.1 & 9.3 & 3.6 & 3.5 \\
\hline Straw & 6.0 & 3.5 & 8.0 & 8.1 & 8.8 & 3.3 & 3.8 \\
\hline Green manure $1^{\text {st }}$ cut + straw & 6.0 & 4.0 & 8.6 & 7.4 & 9.0 & 3.8 & 3.5 \\
\hline Green manure $2^{\text {nd }}$ cut + straw & 6.0 & 4.5 & 8.1 & 7.3 & 9.1 & 3.8 & 4.0 \\
\hline Farmyard manure $40 \mathrm{t} \mathrm{ha}^{-1}+$ straw & 6.1 & 4.2 & 8.1 & 7.4 & 8.8 & 3.4 & 3.5 \\
\hline \multicolumn{8}{|c|}{ Deep loosening (factor $\mathrm{C}$ ) } \\
\hline Unloosened & 5.9 & 3.8 & 8.2 & 7.5 & 8.7 & 3.7 & 3.7 \\
\hline Loosened & $6.4 *$ & 4.2 & 8.2 & 7.8 & 9.2 & 3.5 & 3.6 \\
\hline \multicolumn{8}{|c|}{ Interaction of factors $\mathrm{A} \times \mathrm{C}$} \\
\hline $\mathrm{A} 1 \times \mathrm{C} 1$ & 5.4 & 4.0 & 7.7 & 6.3 & 8.2 & 3.9 & 3.0 \\
\hline $\mathrm{A} 1 \times \mathrm{C} 2$ & $6.4 * *$ & 4.5 & 6.9 & 6.3 & $9.3^{*}$ & $3.0^{* *}$ & 3.1 \\
\hline $\mathrm{A} 2 \times \mathrm{C} 1$ & 5.5 & 4.0 & 7.6 & 7.4 & 9.2 & $2.7 * *$ & $3.9^{*}$ \\
\hline $\mathrm{A} 2 \times \mathrm{C} 2$ & 5.8 & 3.5 & 7.4 & 7.3 & $9.7 * *$ & $2.8^{* *}$ & 3.3 \\
\hline $\mathrm{A} 3 \times \mathrm{C} 1$ & $6.7 * *$ & 3.4 & $9.7 * *$ & $8.7 * *$ & 8.9 & 4.4 & $4.2 * *$ \\
\hline $\mathrm{A} 3 \times \mathrm{C} 2$ & $6.8^{* *}$ & 4.5 & $9.8^{* *}$ & $9.7 * *$ & 8.7 & $4.7 *$ & $4.3 * *$ \\
\hline
\end{tabular}

* - significant at $P \leq 0.05, * *$ - significant at $P \leq 0.01$

In the crops of all experimental years the annual weeds dominated $(96.5 \%)$. Crop weed incidence depended not only on soil tillage methods and agrotechnical measures, but also on the other factors (plant species peculiarities, meteorological conditions). The amount of precipitation during the plant growing season is an important indicator of meteorological conditions. Statistical analysis of the research results showed that the linear correlation between the amount of precipitation (x) from $1^{\text {st }}$ of March to first assessment (stage of shooting) and from $1^{\text {st }}$ of March to second assessment (stage of maturity), and weediness indicators (y) weed number, dry matter mass and number of species, during the shooting and maturity stage was strong $(r=$ from $0.70^{*}$ to $\left.0.91^{* *}\right)$. This shows that the amount of precipitation influenced crop weediness from $50 \%$ to $83 \%$ (crop weediness increased with increasing amount of precipitation). Due to more favourable meteorological conditions, weed spread more abundantly in 2013 and 2014 during the first half of plant growing season.

Soil tillage methods influenced weed specific composition independently from soil fertility maintenance measures and deep loosening. Viola arvensis Murray dominated in winter wheat stand (2012) during the shooting stage in deep and shallow ploughed soil, and Poa аппиа L. dominated in shallow ploughless tillage plots. Chenopodium album L. dominated in spring rape (2013) and spring barley stands (2014) in deep and shallow ploughed soil, whereas in shallow ploughless tillage plots species diversity was greater, respectively: C. album L., P. annua L., Raphanus raphanistrum L. and Spergula arvensis $\mathrm{L}$.

Later in the growing season, during the plant maturity, soil tillage methods influence on weed species diversity was not determined. $P$. аппиа dominated in winter wheat (2012) and C. album dominated in spring rape (2013) and spring barley (2014) stands.

\section{Conclusions}

1. Primary soil tillage method had significant impact on the weed incidence in the crop rotation in all experimental years. In shallow tillage soil, the number of weeds and dry mass were significantly greater as well as the diversity of weed species compared to the deep ploughing treatments.

2. The influence of a onetime deep loosening was significant in the first year. After improvement of soil aeration and humidity conditions, the weed number and weed dry mass were significantly greater compared to unloosened plots. A significant interaction was observed between deep loosening and soil tillage methods. After deep loosening in shallow tillage, the weed number was greater, compared to that in the conventionally ploughed soil. After deep loosening, in the first and the second year, during the shooting stage in winter wheat and during the shooting and maturity stages in spring rape stands, the weed species composition was significantly greater in shallow tillage soil compared to conventional ploughing.

3. Organic fertilizers did not have any significant influence on weed incidence indicators; however, the use of red clover of the first cut for green manure tended to reduce weed number in the crop rotation in the first half of the growing season.

4. A strong correlation ( $r=$ from $0.70 *$ to $0.91 * *$ ) was determined between the amount of precipitation from the $1^{\text {st }}$ of March until shooting stage and from the $1^{\text {st }}$ of March until maturity stage and weed incidence indicators (weed number, dry mass and species number) at shooting and maturity stages.

\section{Acknowledgments}

The paper presents research findings, obtained through project "The influence of long-term contrasting 
intensity resources management on genesis of different soils and to other agro-ecosystems components" (SIT9/2015) financed by Research Council of Lithuania.

Received 09112015 Accepted 13042016

\section{References}

Al-Kaisi M. M., Douelle A., Kwaw-Mensah D. 2014. Soil microaggregate and macroaggregate decay over time and soil carbon changes as influenced by different tillage system. Journal of Soil and Water Conservation, 69 (6): $574-580$

http://dx.doi.org/10.2489/jswc.69.6.574

Baležentienè L. 2008. Organic and intensive farming impact on phytodiversity. Žemès ūkio mokslai, 79 (32): 30-42

Booth B. D., Murphy S. D., Swanton C. J. 2003. Weed ecology in natural and agricultural system. Walingford, UK, p. $29-41$ http://dx.doi.org/10.1079/9780851995281.0029

Clewer A. G., Scarisbrick D. H. 2001. Practical statistics and experimental design for plant and crop science. New York, USA, $346 \mathrm{p}$.

Colbach N., Busset H., Yamada O., Durr C., Caneill J. 2006. ALOMYSYS: modelling blackgrass (Alopecurus myosuroides Huds.) germination and emergence, in interaction with seed characteristics, tillage and soil climate. II. Evaluation. European Journal of Agronomy, 24 (29): 113-128 http://dx.doi.org/10.1016/j.eja.2005.07.002

Čiuberkis S., Ožeraitienė D., Bernotas S., Ambrazaitienė D. 2008. Changes in the soil properties as affected by conventional and minimal soil tillage systems. Zemdirbyste-Agriculture, 95 (2): 16-23

De Sanctis G., Roggero P. P., Seddaiu G., Orsini R., Porter C. H., Jones J. W. 2012. Long-term no tillage increased soil organic carbon content of rain-fed cereal systems in a Mediterranean area. European Journal of Agronomy, 40: 18-27

http://dx.doi.org/10.1016/j.eja.2012.02.002

Dorado J., Lopez-Fando C. 2006. The effect of tillage system and use of a paraplow on weed flora in a semiarid soil from central Spain. Weed Research, 46: 424-431 http://dx.doi.org/10.1111/j.1365-3180.2006.00526.x

Edesi L., Järvan M., Adamson A., Lauringson E., Kuht J. 2012. Weed species diversity and community composition in conventional and organic farming: a five-year experiment. Zemdirbyste-Agriculture, 99 (4): 339-346

Eiswerth M. E., Haney J. C. 2001. Maximizing conserved biodiversity: why ecosystem indicators and thresholds matter. Ecological Economics, 38 (2): 259-274 http://dx.doi.org/10.1016/S0921-8009(01)00166-5

Grundy A. C. 1997. The influence of temperature and water potential on the germination of seven different dry-stored seed lots of Stellaria media. Weed Research, 37: 251-266 http://dx.doi.org/10.1046/j.1365-3180.1997.d01-40.x

Hyvönen T., Salonen J. 2002. Weed species diversity and community composition in cropping practices at two intensity levels - a six-year experiment. Plant Ecology, 159: $73-81$

http://dx.doi.org/10.1023/A:1015580722191

Jodaugiene D. 2002. The peculiarities of underground and overground parts of Triticum aestivum winter varieties 'Širvinta 1' and 'Zentos' under the conditions of different soil tillage. Zemdirbyste-Agriculture, 77: 59-69
Kinderienè I. 2014. The change of weed abundance in cereals using the ploughless soil tillage on eroded soils. Žemès ūkio mokslai, 21 (3): 151-160

Kolárová M., Tyšer L., Soukup J. 2013. Diversity of current weed vegetation on arable land in selected areas of the Czech Republic. Plant, Soil and Environment, 59 (5): 208-213

Maikštėnienė S., Arlauskienė A., Velykis A., Satkus A. 2009. Enhancement of competitive ability of cereals towards weeds by means of crop rotations. ZemdirbysteAgriculture, 96 (2): 23-34

Murphy S. D., Clements D. R., Belaoussoff S., Kevan P. G., Swanton C. J. 2006. Promotion of weed species diversity and reduction of weed seedbanks with conservation tillage and crop rotation. Weed Science, 54 (1): 69-77 http://dx.doi.org/10.1614/WS-04-125R1.1

Novara A., Armstrong A., Gristina L., Semple K. T., Quinton J. N. 2012. Effects of soil compaction, rain exposure and their interaction on soil carbon dioxide emission. Earth Surface Processes and Landforms, 37 (9): 994-998 http://dx.doi.org/10.1002/esp.3224

Olesen J. E., Munkholm L. J. 2007. Subsoil loosening in a crop rotation for organic farming eliminated plough pan with mixed effects on crop yield. Soil and Tillage Research, 94 (2): $376-385$ http://dx.doi.org/10.1016/j.still.2006.08.015

Onofri A., Carbonell E. A., Piepho H.-P., Mortimer A. M., Cousens R. D. 2010. Current statistical issues in Weed Research. Weed Research, 50 (1): 5-24 http://dx.doi.org/10.1111/j.1365-3180.2009.00758.x

Sans F. X., Berner A., Armengot L., Mäder P. 2011. Tillage effects on weed communities in an organic wheatsunflower-spelt cropping sequence. Weed Research, 51: $413-421$ http://dx.doi.org/10.1111/j.1365-3180.2011.00859.x

Skuodiene R., Nekrosiene R. 2012. The effects of perennials as green manure on cereal productivity and disease incidence. Spanish Journal of Agricultural Research, 10 (1): 44-54 http://dx.doi.org/10.5424/sjar/2012101-025-11

Skuodienė R., Karčauskienė D., Čiuberkis S., Repšienė R., Ambrazaitienè D. 2013. The influence of primary soil tillage on soil weed seed bank and weed incidence in a cereal-grass crop rotation. Zemdirbyste-Agriculture, 100 (1): $25-32$ http://dx.doi.org/10.13080/z-a.2013.100.004

Stancevičius A., Špokienė N., Jodaugienė D., Trečiokas K., Raudonius S. 2002. Supaprastinto žemès dirbimo itaka pasèlių piktžolètumui. Vagos, 55 (8): 50-57

Szumigalski A., Van Acker R. 2005. Weed suppression and crop production in annual intercrops. Weed Science, 53 (6): $813-825$ http://dx.doi.org/10.1614/WS-05-014R.1

Torresen K. S., Skuterud R., Tansaether H. J., Hagemo M. B. 2003. Long-term experiments with reduced tillage in spring cereals. I. Effects on weed flora, weed seedbank and grain yield. Crop Protection, 22: 185-200 http://dx.doi.org/10.1016/S0261-2194(02)00145-X

Velykis A., Satkus A. 2012. Effect of reduced clay loam tillage on weed infestation and spring barely yield. Žemès ūkio mokslai, 19 (4): 236-248

Woźniak A., Soroka M. 2015. Biodiversity of weeds in pea cultivated in various tillage system. Romanian Agricultural Research, 32: 231-237 
ISSN 1392-3196 / e-ISSN 2335-8947

Zemdirbyste-Agriculture, vol. 103, No. 2 (2016), p. 135-142

DOI $10.13080 / \mathrm{z}-\mathrm{a} .2016 .103 .018$

\title{
Žemės dirbimo būdų, giluminio purenimo ir organinio tręšimo įtaka pasėlių piktžolètumui
}

\author{
R. Skuodienè, D. Karčauskienė, R. Repšienè \\ Lietuvos agrarinių ir miškų mokslų centro Vėžaičių filialas
}

\section{Santrauka}

Nedaug žinoma apie dirvožemio giluminio purenimo, jị derinant su nevienodo intensyvumo pagrindiniu žemès dirbimu ir tręšimu įvairiomis organinėmis trąšomis, poveikị sejomainos pasėlių piktžolètumui. Tyrimų tikslas nustatyti ịvairių žemės dirbimo būdų ir jų derinių su giluminiu purenimu bei organinėmis trąšomis įtaką sèjomainos pasèlių piktžolètumui. Tyrimai atlikti Lietuvos agrarinių ir miškų mokslų centro Vèžaičių filiale 2012-2015 m. keturių narių sèjomainoje: žieminiai kviečiai $\rightarrow$ vasariniai rapsai $\rightarrow$ vasariniai miežiai su raudonujų dobilų įsèliu $\rightarrow$ raudonieji dobilai. Bandymo dirvožemis - nepasotintasis sekliai glejjiškas balkšvažemis (JIg8-n), granuliometrinė sudètis - smèlingas priemolis.

Žemès dirbimo būdų (gilaus arimo, seklaus arimo, seklaus neariminio dirbimo), organinių trąšų (be organinių trąšų, šiaudai, I pjūties žalioji trąša + šiaudai, II pjūties žalioji trąša + šiaudai, méšlas $40 \mathrm{t} \mathrm{ha}^{-1}+$ šiaudai) ir giluminio purenimo poveikis piktžolių plitimui tyrimų metais buvo labai nevienodas ir priklausè nuo sejjomainos pasèlių vystymosi sąlygų.

Tirtiems piktžolètumo rodikliams (piktžolių skaičiui ir jų masei) visais tyrimų metais esminès įtakos turèjo rudeninis žemès dirbimo būdas. Bendras piktžolių skaičius ir jų masẻ buvo iš esmės didesni sekliai dirbtame dirvožemyje. Organinès trąšos esminès ịtakos piktžolètumo rodikliams neturẻjo, tačiau pirmosios pjūties raudonųjų dobilų panaudojimas žaliajai trąšai turejo tendenciją mažinti piktžolių skaičių sėjomainos pasėliuose augalų vegetacijos pirmoje pusèje. Vienkartinio giluminio purenimo esminè įtaka tiesiogiai pasireiške pirmaisiais metais. Pagerinus dirvožemio aeracines ir drègmès sąlygas, piktžolių skaičius bei jų sausujų medžiagų masė buvo iš esmès didesni, palyginus su taip nepurentais laukeliais. Giluminio purenimo esmine įtaka pasireiškè ir sąveika su žemės dirbimo būdais. Taikant giluminị purenimą sekliai dirbtame dirvožemyje piktžolių skaičius daugeliu atveju buvo didesnis, palyginus su giliai suarta dirva.

Reikšminiai žodžiai: dirvožemio derlingumą palaikančios priemonės, piktžolių skaičius ir jų masė, žemės dirbimas rudeni.

Please use the following format when citing the article:

R. Skuodienè, D. Karčauskienè, R. Repšienè. 2016. The influence of primary soil tillage, deep loosening and organic fertilizers on weed incidence in crops. Zemdirbyste-Agriculture, 103 (2): 135-142 DOI 10.13080/z-a.2016.103.018 